\title{
Review \\ The Antimicrobial Effect of Cold Atmospheric Plasma against Dental Pathogens-A Systematic Review of In-Vitro Studies
}

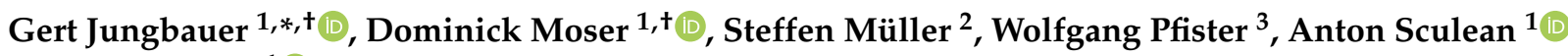 \\ and Sigrun Eick ${ }^{1}$ (1) \\ 1 Department of Periodontology, School of Dental Medicine, University of Bern, 3010 Bern, Switzerland; \\ dominick.moser@bluewin.ch (D.M.); anton.sculean@zmk.unibe.ch (A.S.); sigrun.eick@zmk.unibe.ch (S.E.) \\ 2 Department of Cranio-Maxillofacial Surgery, Hospital of the University of Regensburg, \\ 93053 Regensburg, Germany; steffen.mueller@ukr.de \\ 3 Department of Hospital Hygiene, Sophien- und Hufeland-Klinikum Weimar, 99425 Weimar, Germany; \\ W.Pfister@klinikum-weimar.de \\ * Correspondence: gert.jungbauer@zmk.unibe.ch \\ + Both authors contributed equally.
}

Citation: Jungbauer, G.; Moser, D.; Müller, S.; Pfister, W.; Sculean, A.; Eick, S. The Antimicrobial Effect of Cold Atmospheric Plasma against Dental Pathogens-A Systematic Review of In-Vitro Studies. Antibiotics 2021, 10, 211. https://doi.org/ 10.3390/antibiotics10020211

Academic Editor: Tetsuya Adachi

Received: 1 February 2021

Accepted: 18 February 2021

Published: 20 February 2021

Publisher's Note: MDPI stays neutral with regard to jurisdictional claims in published maps and institutional affiliations.

Copyright: (c) 2021 by the authors. Licensee MDPI, Basel, Switzerland. This article is an open access article distributed under the terms and conditions of the Creative Commons Attribution (CC BY) license (https:/ / creativecommons.org/licenses/by/ $4.0 /)$.

\begin{abstract}
Interest in the application of cold atmospheric plasma (CAP) in the medical field has been increasing. Indications in dentistry are surface modifications and antimicrobial interventions. The antimicrobial effect of CAP is mainly attributed to the generation of reactive oxygen and reactive nitrogen species. The aim of this article is to systematically review the available evidence from in-vitro studies on the antimicrobial effect of CAP on dental pathogens. A database search was performed (PubMed, Embase, Scopus). Data concerning the device parameters, experimental setups and microbial cultivation were extracted. The quality of the studies was evaluated using a newly designed assessment tool. 55 studies were included (quality score 31-92\%). The reduction factors varied strongly among the publications although clusters could be identified between groups of set pathogen, working gases, and treatment time intervals. A time-dependent increase of the antimicrobial effect was observed throughout the studies. CAP may be a promising alternative for antimicrobial treatment in a clinically feasible application time. The introduced standardized protocol is able to compare the outcome and quality of in-vitro studies. Further studies, including multi-species biofilm models, are needed to specify the application parameters of CAP before CAP should be tested in randomized clinical trials.
\end{abstract}

Keywords: cold atmospheric plasma; non-thermal plasma; antimicrobial; dentistry; Streptococcus mutans; Enterococcus faecalis; Candida albicans; periodontal disease; peri-implant disease; in vitro

\section{Introduction}

The application of physical plasma in medicine is a promising tool for disinfection and therefore a lot of data has been published within the last decade. Developed to nonchemically decontaminate in biomedical and food industries, cold atmospheric plasma (CAP) has emerged in the medical field. Plasma, often referred to as the 'fourth state of matter', is an ionized gas with approximately neutral charge. Terms such as non-thermal and atmospheric pressure plasma further describe the nature of the physical plasma, which operates under atmospheric pressure and does not exceed $50{ }^{\circ} \mathrm{C}$ and is therefore tolerable for human tissues. Plasma sources can be divided into indirect and direct plasma devices. In an indirect plasma device, commonly constructed as a jet design, plasma is generated by ionization of the working gas between two electrodes and constantly pushed out by the gas flow. In a direct plasma device-such as a plasma brush, volume dielectric barrier discharge (VDBD), or corona discharge device-plasma is generated between the electrode of the device and the treated surface, which functions as a grounded electrode. These devices can operate by utilizing ambient air [1]. 
Indications of CAP application in dentistry are: bonding to dentin and ceramics, curing of composites, bleaching, surface activation of dental implants, and antimicrobial therapeutic interventions in cariology, endodontology, periodontology, and implantology [2]. The microbicidal properties are based on the generation of reactive oxygen (ROS) and nitrogen species (RNS) including free radicals, charged particles, electric fields, and electric radiation such as UV radiation. Subsequently, these physical processes lead to antimicrobial effects, most probably caused by oxidation of cell membranes and DNA [3] Various structures of the microbes are targeted by ROS and RNS, the cell wall is etched, and the membrane is damaged by disruption and lipid peroxidation. The bacterial DNA and RNA are impaired by oxidative damage, base modification, and strand breaks. Furthermore macromolecules, like proteins may become unfolded or modified [3]. Most dental treatments are aiming to remove or disrupt the oral biofilms. An ecological shift towards an anaerobic environment, especially when an adequate removal of the biofilm is hampered, leads to an establishment of anaerobic bacteria within the biofilm [4]. In the initial biofilm formation on the tooth surface, non-mutans streptococci-like Streptococcus mitis and Streptococcus sanguinis-are early colonizers causing acidification and introduction of more cariogenic microorganisms like Streptococcus mutans [5]. Lactobacilli, especially the subspecies L. acidophilus, L. rhamnosus, L. casei, and L. fermentum are often found in active carious lesions and therefore highly associated with increased caries activity [6]. Enterococcus faecalis is commonly known in the context of hospital acquired infections. In dentistry, this Gram-positive bacterium is frequently identified in reinfected root canals [7]. Porphyromonas gingivalis and Aggregatibacter actinomycetemcomitans are Gram-negative, anaerobic rods highly associated with periodontal disease [8]. P. gingivalis is capable in breaking down the host immunotolerance and is therefore referred to as the keystone-pathogen in periodontitis [9]. Some yeast strains, mainly Candida albicans, are opportunistic pathogens found in oral infections. Primarily known for causing denture stomatitis, C. albicans can also be isolated from infected root canals and periodontal or peri-implant pockets, especially in immune compromised patients.

To the best of our knowledge, until now no systematic review has attempted to analyze the available literature on the potential antimicrobial effects of the in-vitro application of cold atmospheric plasma. Therefore, the aim of this systematic review was to analyze the available literature regarding the antimicrobial effects of in-vitro application of cold atmospheric plasma on various types of oral microorganisms.

\section{Methods}

\subsection{Search Strategy}

The search was performed based on the PRISMA statement [10]. The following focused question was formulated: "Does the in-vitro application of cold atmospheric plasma show an antimicrobial effect compared to no treatment on pathogens related to dentistry?" According to the PICO criteria defined from the focused question (Figure 1b), a database search was conducted in PubMed (Medline), Embase and Scopus on 19 October 2020 by two authors separately (G.J. and D.M.).

The results were restricted to research articles written in English. The keywords for the PubMed search were: ("cold atmospheric plasma" OR "non-thermal plasma" OR "nonthermal plasma" OR "non-thermal atmospheric plasma" OR "non thermal atmospheric plasma" OR "non-thermal atmospheric pressure plasma" OR "non thermal atmospheric pressure plasma" OR "cold atmospheric pressure plasma" OR "argon plasma" OR "helium plasma" OR "oxygen plasma" OR "nitrogen plasma" OR "air plasma" OR "plasma gases" OR "plasma jet" OR "dielectric barrier discharge" OR "glow discharge" [MeSH Terms]) AND ("dentistry" OR "dental treatment" OR "dental therapy" OR "oral") AND ("disinfection" OR "sterilization" OR "bacterial inactivation" OR "bactericidal" OR "bacteriostatic" OR "antibacterial" OR "anti-bacterial" OR "microbicidal" OR "antimicrobial" OR "anti-microbial" OR "antifungal" OR "anti-fungal" OR "antiviral" OR "anti-viral") AND ("in-vitro" OR "in vitro"). For Scopus, the keywords were chosen in the same way and for 
Embase the PICO manager was used. References from relevant articles were assessed and added when appropriate.

(a)
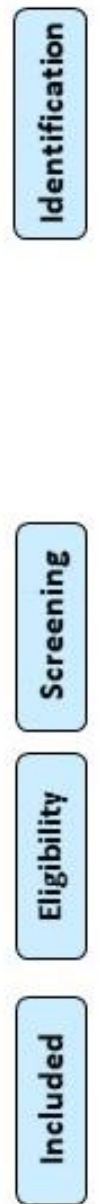

(b)

\begin{tabular}{|l|l|}
\hline Participants & pathogens related to dentistry \\
\hline Intervention & application of plasma \\
\hline Comparison & no treatment \\
\hline Outcome & antimicrobial effect \\
\hline Study design & In-vitro studies \\
\hline
\end{tabular}

Records excluded

$$
(n=2262)
$$

Full-text articles excluded, with reasons $(n=34)$

Figure 1. (a) Flow diagram of studies screened, assessed for eligibility, and included; (b) PICO framework, according to the PRISMA checklist [10].

\subsection{Eligibility Criteria}

In-vitro studies investigating the direct application of plasma on pathogens associated with dental diseases were included in the analysis. Therefore, only studies focusing on streptococci, lactobacilli, E. faecalis, $P$. gingivalis, and A. actinomycetemcomitans were considered. To compare the outcome only studies specifying the reduction in $\log _{10}$ colony forming units (CFU) were included. If the reduction factor (RF) was not outlined, it was calculated using the formula: $\mathrm{RF}=-\log _{10}\left(\mathrm{CFU}_{\text {treatment }} / \mathrm{CFU}_{\text {control }}\right)$. Results were presented with one decimal place. Reductions less than about $0.5 \log _{10}$ were categorized as non-relevant and declared as 'no reduction'. Studies not using a control group were excluded. As control no treatment (no Tx), rinsing with sodium chloride $(\mathrm{NaCl})$ or phosphate buffered saline (PBS) or working gas without plasma ignition was accepted. Furthermore, studies investigating the indirect plasma activity on bacteria, i.e., plasma activated water or bacteria in suspension were excluded. 


\subsection{Data Extraction and Assessment of Quality}

The data extraction was performed by two authors (G.J. and D.M.) using a piloted form, which included technical parameters of the plasma device, characteristics of the study setup like nozzle-specimen distance, biofilm growth duration, and RF for set treatment time intervals (Table S1). In order to create a comprehensive overview, an additional table was made summarizing RFs for the specific working gases and treatment intervals (Tables 2-5). Disagreements in extracted results were resolved by discussion. To assess the quality of the publications, an assessment tool based on the US EPA protocol and standards for bactericidal activities of disinfectants [11-15] was created. The tool consists of 11 items, nine with one point and two with two points attainable. A maximum score of 13 points in total could be achieved. The final score was expressed as a percentage of achieved points divided by maximum points multiplied by 100. The items evaluated the reproducibility and critical steps within the study protocol that may overestimate the outcome. The detailed description of the assessment tool can be found in Table 1.

\subsection{Statistical Analysis}

The RFs were extracted from tables or read from graphs. The inter-rater reliability for the extracted RFs was calculated using the Intraclass correlation coefficient (ICC; two-way mixed, absolute agreement). ICC $<0.5,0.5-0.75,0.75-0.9,>0.9$ were interpreted as poor, moderate, good, and excellent reliability respectively [16]. For the quality assessment the inter-rater reliability using Cohen's kappa coefficient was calculated [17] with the assumption of $\kappa>0.8 / 0.6 / 0.4 / 0.2 / 0$ as almost perfect, substantial, moderate, fair or slight respectively and $\mathrm{k}<0$ as poor agreement [18]. The calculation was performed with SPSS 24 (IBM, Armonk, NY, USA).

\section{Results}

After the duplicates were removed, 2323 articles were screened. Following exclusion by title and abstract, 109 articles could be assessed for eligibility (Figure 1a). Thirty-four studies were excluded because the authors defined another outcome than CFU, four articles did not compare the application of plasma with an untreated control, four treated bacteria in suspension and in five papers the effect on bacterial adhesion and de novo biofilm formation was analyzed. Eight articles did not investigate the antifungal effect related to a dental aspect. The remaining 55 publications were included in the qualitative synthesis (Tables 2-5). Seventeen articles investigated the antibacterial effect on planktonic bacteria and 37 on bacterial biofilms. One investigated both. Sixteen studies used extracted teeth or a realistic resin tooth model. There, single rooted teeth were decoronated and the root canals were instrumented, before the roots were sterilized, inoculated, and incubated. The inter-rater agreement for the extracted RFs was excellent (ICC: 0.993). 
Table 1. Quality assessment tool.

\begin{tabular}{|c|c|c|c|}
\hline Critical Steps of the in Vitro Protocol & Justification & Items & $\begin{array}{l}\text { Points Attributed According to the Response } \\
\text { for Each Critical Step }\end{array}$ \\
\hline \multirow[t]{2}{*}{$\begin{array}{l}\text { Preparation of micro-organisms and } \\
\text { plasma device }\end{array}$} & \multirow[t]{2}{*}{ Scientific robustness } & 1. Preparation of microorganisms & $\begin{array}{c}1 \text { if described } \\
0 \text { if not described }\end{array}$ \\
\hline & & 2. Technical data of plasma generator & $\begin{array}{c}2 \text { if at least } 3 \text { parameters described or } \\
\text { commercially device } \\
1 \text { if at least } 1 \text { parameter described } \\
0 \text { if not described }\end{array}$ \\
\hline \multirow[t]{2}{*}{ Test conditions } & \multirow[t]{2}{*}{ Scientific robustness } & 4. Experimental temperature & $\begin{array}{c}1 \text { if described } \\
0 \text { if not described or over } 47^{\circ} \mathrm{C}\end{array}$ \\
\hline & & 5. Protection of samples & $\begin{array}{c}1 \text { if described } \\
0 \text { if not described }\end{array}$ \\
\hline $\begin{array}{l}\text { Micro-organisms } \\
\text { recovery }\end{array}$ & $\begin{array}{c}\text { Impacts the results if not all micro-organisms } \\
\text { are recovered, overestimated effect Scientific } \\
\text { robustness }\end{array}$ & 6. Micro-organisms recovery & $\begin{array}{c}1 \text { if other method with mechanic action and } \\
\text { validated with a test } \\
0 \text { if not clearly described or technic not validated }\end{array}$ \\
\hline \multirow[t]{2}{*}{ Microbial culture after treatment } & \multirow{2}{*}{$\begin{array}{l}\text { Impacts the results if the growth duration is } \\
\text { too short Scientific robustness }\end{array}$} & 7. Time, temperature and method indicated & $\begin{array}{c}1 \text { if described } \\
0 \text { if not or poorly described }\end{array}$ \\
\hline & & 8. Culture media & $\begin{array}{c}1 \text { if described } \\
0 \text { if not described }\end{array}$ \\
\hline \multirow[t]{2}{*}{ Statistical analysis/tests repeatability } & \multirow[t]{2}{*}{ Scientific robustness } & 9. Number of experiments & $\begin{array}{c}1 \text { if described with more than one } \\
\text { experiment } \\
0 \text { if not described or described with onlyone } \\
\text { experiment }\end{array}$ \\
\hline & & 10. Statistical method (to compare differences) & $\begin{array}{c}1 \text { if described } \\
0 \text { if not described }\end{array}$ \\
\hline Conflict of Interest & Bias & 11. Declaration & $\begin{array}{c}1 \text { if declared } \\
0 \text { if not declared }\end{array}$ \\
\hline
\end{tabular}

The global score was calculated by summing each point (score = sum/13*100). 


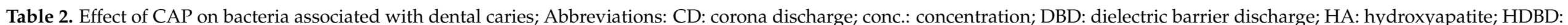

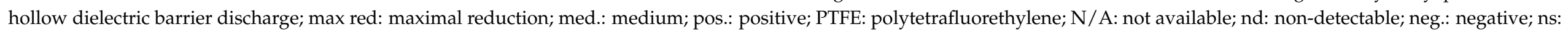
non-significant; self-constr.: self-constructed; Ti: titanium; VDBD: volume dielectric barrier discharge.

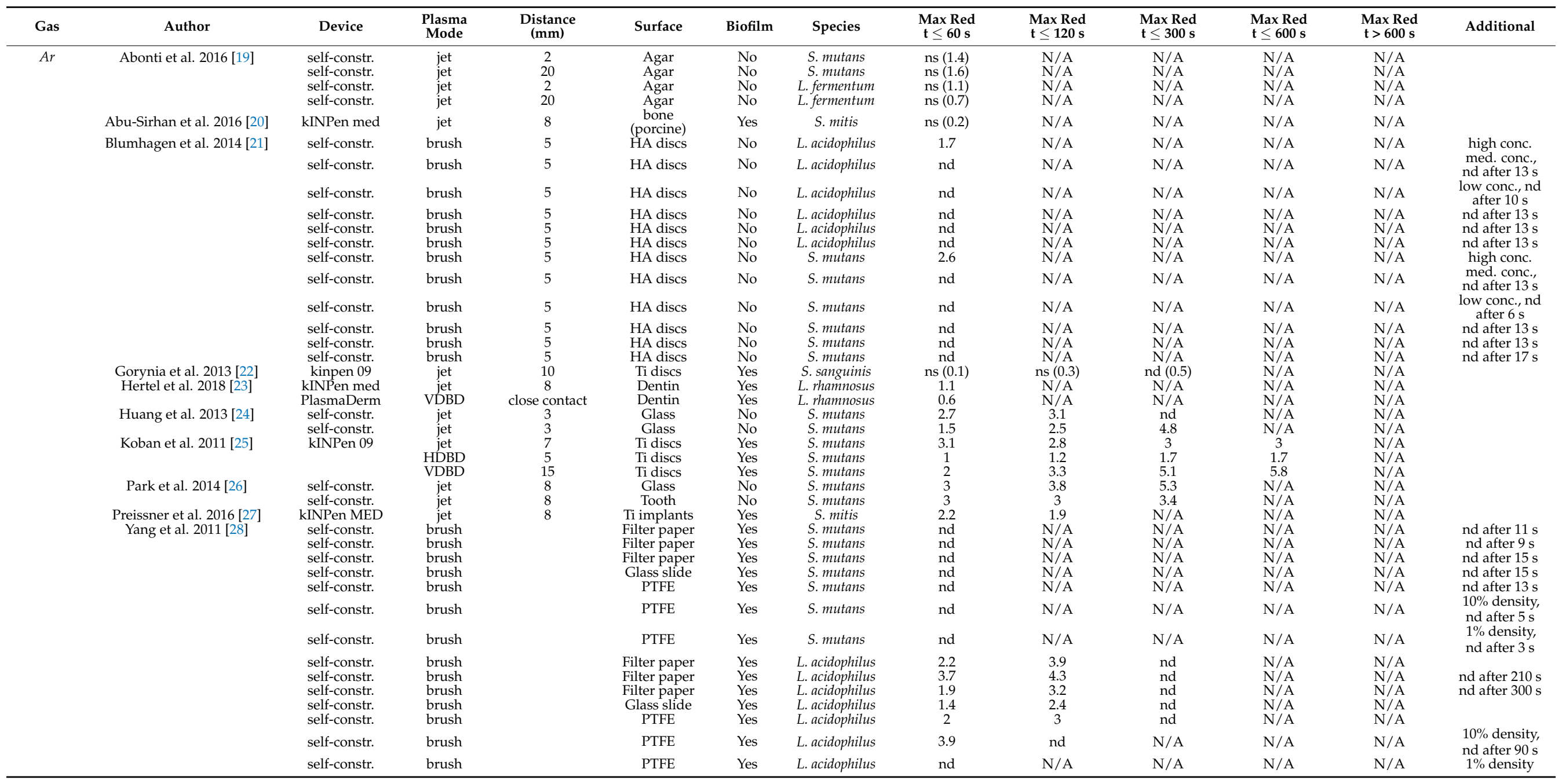


Table 2. Cont.

\begin{tabular}{|c|c|c|c|c|c|c|c|c|c|c|c|c|c|}
\hline Gas & Author & Device & $\begin{array}{l}\text { Plasma } \\
\text { Mode }\end{array}$ & $\begin{array}{c}\text { Distance } \\
(\mathrm{mm})\end{array}$ & Surface & Biofilm & Species & $\begin{array}{c}\text { Max Red } \\
t \leq 60 \mathrm{~s}\end{array}$ & $\begin{array}{l}\text { Max Red } \\
t \leq 120 \mathrm{~s}\end{array}$ & $\begin{array}{l}\text { Max Red } \\
t \leq 300 \mathrm{~s}\end{array}$ & $\begin{array}{l}\text { Max Red } \\
t \leq 600 \mathrm{~s}\end{array}$ & $\begin{array}{c}\text { Max Red } \\
t>600 s\end{array}$ & Additional \\
\hline \multirow[t]{5}{*}{$\mathrm{Ar}+\mathrm{O}_{2}$} & Blumhagen et al. 2014 [21] & self-constr. & brush & 5 & HA discs & Yes & L. acidophilus & nd & N/A & N/A & N/A & N/A & $\begin{array}{l}\mathrm{Ar} / \mathrm{O}_{2}: 60: 1, \\
\text { nd after 13s }\end{array}$ \\
\hline & & self-constr. & brush & 5 & HA discs & Yes & L. acidophilus & nd & $\mathrm{N} / \mathrm{A}$ & $\mathrm{N} / \mathrm{A}$ & $\mathrm{N} / \mathrm{A}$ & $\mathrm{N} / \mathrm{A}$ & $\begin{array}{l}\mathrm{Ar} / \mathrm{O}_{2}: 6: 1, \\
\text { nd after } 13 \mathrm{~s}\end{array}$ \\
\hline & & self-constr. & brush & 5 & HA discs & Yes & S. mutans & nd & N/A & $\mathrm{N} / \mathrm{A}$ & $\mathrm{N} / \mathrm{A}$ & $\mathrm{N} / \mathrm{A}$ & $\begin{array}{l}\mathrm{Ar} / \mathrm{O}_{2}: 300: 5 \text {, } \\
\text { nd after } 13 \mathrm{~s}\end{array}$ \\
\hline & & self-constr. & brush & 5 & HA discs & Yes & S. mutans & nd & $\mathrm{N} / \mathrm{A}$ & N/A & $\mathrm{N} / \mathrm{A}$ & N/A & $\begin{array}{l}\mathrm{Ar} / \mathrm{O}_{2}: 6: 1 \\
\text { nd after 13s }\end{array}$ \\
\hline & & self-constr. & brush & 5 & HA discs & Yes & S. mutans & nd & $\mathrm{N} / \mathrm{A}$ & $\mathrm{N} / \mathrm{A}$ & $\mathrm{N} / \mathrm{A}$ & $\mathrm{N} / \mathrm{A}$ & $\begin{array}{l}\mathrm{Ar} / \mathrm{O}_{2}: 1: 2, \\
\text { nd after } 17 \mathrm{~s}\end{array}$ \\
\hline Air & $\begin{array}{c}\text { Hertel et al. } 2018 \text { [23] } \\
\text { Kovalova et al. } 2014 \text { [30] } \\
\text { Liguori et al. } 2017 \text { [31] }\end{array}$ & $\begin{array}{l}\text { PlasmaDerm } \\
\text { self-constr. } \\
\text { self-constr. } \\
\text { self-constr. } \\
\text { self-constr. } \\
\text { self-constr. } \\
\text { self-constr. }\end{array}$ & $\begin{array}{c}\text { VDBD } \\
\text { pos. CD } \\
\text { neg. CD } \\
\text { DBD-Rod } \\
\text { DBD-Plate } \\
\text { DBD-Rod } \\
\text { DBD-Plate }\end{array}$ & $\begin{array}{l}0 \\
5 \\
5 \\
3 \\
3 \\
3 \\
3\end{array}$ & $\begin{array}{c}\text { Dentin } \\
\text { Teeth } \\
\text { Teeth } \\
\text { Well Plate } \\
\text { Well Plate } \\
\text { Well Plate } \\
\text { Well Plate }\end{array}$ & $\begin{array}{l}\text { Yes } \\
\text { Yes } \\
\text { Yes } \\
\text { No } \\
\text { No } \\
\text { Yes } \\
\text { Yes }\end{array}$ & $\begin{array}{l}\text { L. rhamnosus } \\
\text { Streptococci } \\
\text { Streptococci } \\
\text { S. mutans } \\
\text { S. mutans } \\
\text { S. mutans } \\
\text { S. mutans }\end{array}$ & $\begin{array}{c}0.6 \\
\text { N/A } \\
\text { N/A } \\
2.1 \\
1.8 \\
0.8 \\
0.6\end{array}$ & $\begin{array}{l}\text { N/A } \\
0.9 \\
0.8 \\
2.9 \\
2.8 \\
1.8 \\
1.6\end{array}$ & $\begin{array}{c}\text { N/A } \\
1 \\
1.3 \\
\text { N/A } \\
\text { N/A } \\
\text { N/A } \\
\text { N/A }\end{array}$ & $\begin{array}{l}\text { N/A } \\
2.6 \\
2.4 \\
\text { N/A } \\
\text { N/A } \\
\text { N/A } \\
\text { N/A }\end{array}$ & $\begin{array}{l}\text { N/A } \\
\text { N/A } \\
\text { N/A } \\
\text { N/A } \\
\text { N/A } \\
\text { N/A } \\
\text { N/A }\end{array}$ & \\
\hline $\mathrm{He}$ & Molnar et al. 2013 [32] & $\begin{array}{l}\text { self-constr. } \\
\text { self-constr. } \\
\text { self-constr. }\end{array}$ & $\begin{array}{l}\text { DBD } \\
\text { DBD } \\
\text { DBD }\end{array}$ & $\begin{array}{l}2 \\
2 \\
2\end{array}$ & $\begin{array}{l}\text { Tooth Slices } \\
\text { Tooth Slices } \\
\text { Tooth Slices }\end{array}$ & $\begin{array}{l}\text { Yes } \\
\text { Yes } \\
\text { Yes }\end{array}$ & $\begin{array}{l}\text { S. mutans } \\
\text { S. mutans } \\
\text { S. mutans }\end{array}$ & $\begin{array}{l}1.3 \\
2.4 \\
2.3\end{array}$ & $\begin{array}{l}\text { nd } \\
\text { nd } \\
\text { nd }\end{array}$ & $\begin{array}{l}\text { N/A } \\
\text { N/A } \\
\text { N/A }\end{array}$ & $\begin{array}{l}\text { N/A } \\
\text { N/A } \\
\text { N/A }\end{array}$ & $\begin{array}{l}\text { N/A } \\
\text { N/A } \\
\text { N/A }\end{array}$ & $\begin{array}{l}\text { high conc. } \\
\text { med. conc. } \\
\text { low conc. }\end{array}$ \\
\hline \multirow[t]{4}{*}{$\begin{array}{c}\mathrm{He}+\mathrm{O}_{2} \\
+\mathrm{N}_{2}\end{array}$} & Rupf et al. 2010 [33] & self-constr. & jet & 1.5 & Agar & Yes & S. mutans & 5.8 & 8.4 & $\mathrm{~N} / \mathrm{A}$ & N/A & N/A & $\begin{array}{l}\mathrm{He} / \mathrm{O}_{2} / \mathrm{N}_{2}: \\
\text { 2:1.2:1.5 }\end{array}$ \\
\hline & & self-constr. & jet & 1.5 & Dentin slice & No & S. mutans & 4 & $\mathrm{~N} / \mathrm{A}$ & $\mathrm{N} / \mathrm{A}$ & $\mathrm{N} / \mathrm{A}$ & $\mathrm{N} / \mathrm{A}$ & $\begin{array}{l}\mathrm{He} / \mathrm{O}_{2} / \mathrm{N}_{2}: \\
2: 1.2: 1.5\end{array}$ \\
\hline & & self-constr. & jet & 1.5 & Agar & Yes & L. casei & nd & nd & $\mathrm{N} / \mathrm{A}$ & $\mathrm{N} / \mathrm{A}$ & $\mathrm{N} / \mathrm{A}$ & $\begin{array}{l}\mathrm{He} / \mathrm{O}_{2} / \mathrm{N}_{2}: \\
2: 1.2: 1.5\end{array}$ \\
\hline & & self-constr. & jet & 1.5 & Dentin slice & No & L. casei & 4.5 & $\mathrm{~N} / \mathrm{A}$ & N/A & N/A & $\mathrm{N} / \mathrm{A}$ & $\begin{array}{l}\mathrm{He} / \mathrm{O}_{2} / \mathrm{N}_{2}: \\
\text { 2:1.2:1.5 }\end{array}$ \\
\hline $\mathrm{N}_{2}$ & Abonti et al. 2016 [19] & $\begin{array}{l}\text { self-constr. } \\
\text { self-constr. } \\
\text { self-constr. } \\
\text { self-constr. } \\
\text { self-constr. }\end{array}$ & $\begin{array}{l}\text { jet } \\
\text { jet } \\
\text { jet } \\
\text { jet } \\
\text { jet }\end{array}$ & $\begin{array}{c}2 \\
20 \\
2 \\
20\end{array}$ & $\begin{array}{l}\text { Agar } \\
\text { Agar } \\
\text { Agar } \\
\text { Agar } \\
\text { HAdiscs }\end{array}$ & $\begin{array}{l}\text { No } \\
\text { No } \\
\text { No } \\
\text { No } \\
\text { Yes }\end{array}$ & $\begin{array}{l}\text { S. mutans } \\
\text { S. mutans } \\
\text { L. fermentum } \\
\text { L. fermentum } \\
\text { S. mutans }\end{array}$ & $\begin{array}{l}6.2 \\
7 \\
1.8 \\
2.3 \\
0.6 \\
\end{array}$ & $\begin{array}{l}\text { N/A } \\
\text { N/A } \\
\text { N/A } \\
\text { N/A } \\
1\end{array}$ & $\begin{array}{l}\text { N/A } \\
\text { N/A } \\
\text { N/A } \\
\text { N/A } \\
\text { N/A }\end{array}$ & $\begin{array}{l}\text { N/A } \\
\text { N/A } \\
\text { N/A } \\
\text { N/A } \\
\text { N/A }\end{array}$ & $\begin{array}{l}\text { N/A } \\
\text { N/A } \\
\text { N/A } \\
\text { N/A } \\
\text { N/A }\end{array}$ & \\
\hline $\mathrm{O}_{2}$ & Abonti et al. 2016 [19] & $\begin{array}{l}\text { self-constr. } \\
\text { self-constr. } \\
\text { self-constr. } \\
\text { self-constr. }\end{array}$ & $\begin{array}{l}\text { jet } \\
\text { jet } \\
\text { jet } \\
\text { jet }\end{array}$ & $\begin{array}{c}2 \\
20 \\
2 \\
20\end{array}$ & $\begin{array}{l}\text { Agar } \\
\text { Agar } \\
\text { Agar } \\
\text { Agar }\end{array}$ & $\begin{array}{l}\text { No } \\
\text { No } \\
\text { No } \\
\text { No }\end{array}$ & $\begin{array}{l}\text { S. mutans } \\
\text { S. mutans } \\
\text { L. fermentum } \\
\text { L. fermentum }\end{array}$ & $\begin{array}{l}\text { nd } \\
\text { nd } \\
2.4 \\
\text { nd }\end{array}$ & $\begin{array}{l}\text { N/A } \\
\text { N/A } \\
\text { N/A } \\
\text { N/A }\end{array}$ & $\begin{array}{l}\text { N/A } \\
\text { N/A } \\
\text { N/A } \\
\text { N/A }\end{array}$ & $\begin{array}{l}\text { N/A } \\
\text { N/A } \\
\text { N/A } \\
\text { N/A }\end{array}$ & $\begin{array}{l}\text { N/A } \\
\text { N/A } \\
\text { N/A } \\
\text { N/A }\end{array}$ & \\
\hline $\mathrm{O}_{2}+\mathrm{N}_{2}$ & Abonti et al. 2016 [19] & $\begin{array}{l}\text { self-constr. } \\
\text { self-constr. } \\
\text { self-constr. } \\
\text { self-constr. }\end{array}$ & $\begin{array}{l}\text { jet } \\
\text { jet } \\
\text { jet } \\
\text { jet }\end{array}$ & $\begin{array}{c}2 \\
20 \\
2 \\
20\end{array}$ & $\begin{array}{l}\text { Agar } \\
\text { Agar } \\
\text { Agar } \\
\text { Agar }\end{array}$ & $\begin{array}{l}\text { No } \\
\text { No } \\
\text { No } \\
\text { No }\end{array}$ & $\begin{array}{l}\text { S. mutans } \\
\text { S. mutans } \\
\text { L. fermentum } \\
\text { L. fermentum }\end{array}$ & $\begin{array}{c}5.2 \\
6.8 \\
\text { ns }(1.7) \\
2.3\end{array}$ & $\begin{array}{l}\text { N/A } \\
\text { N/A } \\
\text { N/A } \\
\text { N/A }\end{array}$ & $\begin{array}{l}\text { N/A } \\
\text { N/A } \\
\text { N/A } \\
\text { N/A }\end{array}$ & $\begin{array}{l}\text { N/A } \\
\text { N/A } \\
\text { N/A } \\
\text { N/A }\end{array}$ & $\begin{array}{l}\text { N/A } \\
\text { N/A } \\
\text { N/A } \\
\text { N/A }\end{array}$ & \\
\hline
\end{tabular}




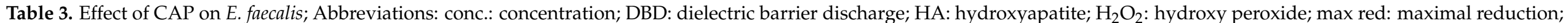
N/A: not available; NaOCl: sodium hypochlorite; nd: non-detectable; ns: non-significant; self-constr.: self-constructed.

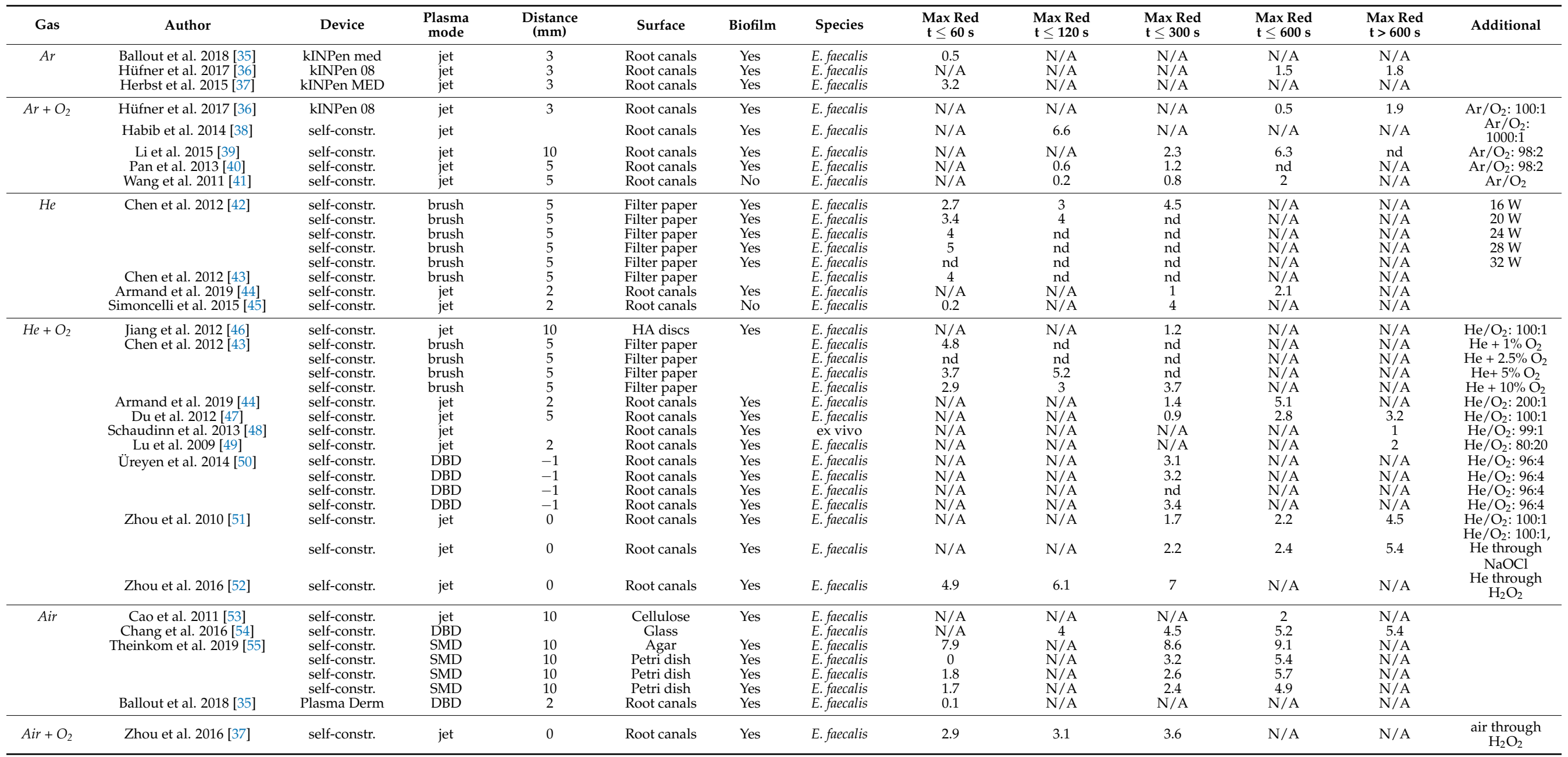




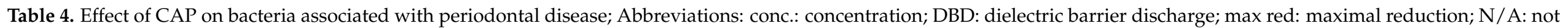
available; nd: non-detectable; ns: non-significant; self-constr.: self-constructed; Ti: titanium.

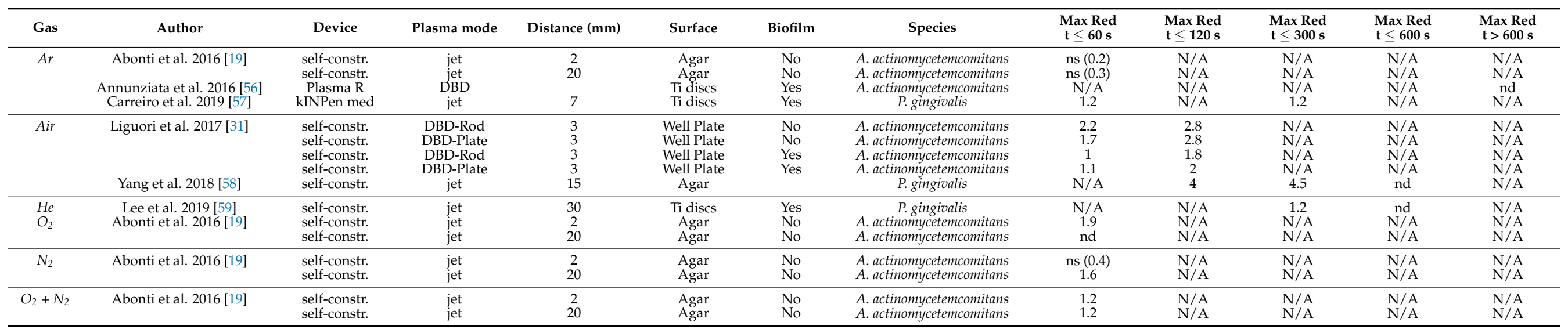




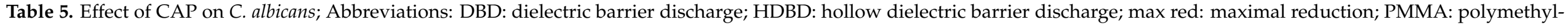
methacrylate; N/A: not available; nd: non-detectable; ns: non-significant; self-constr.: self-constructed; Ti: titanium; VDBD: volume dielectric barrier discharge.

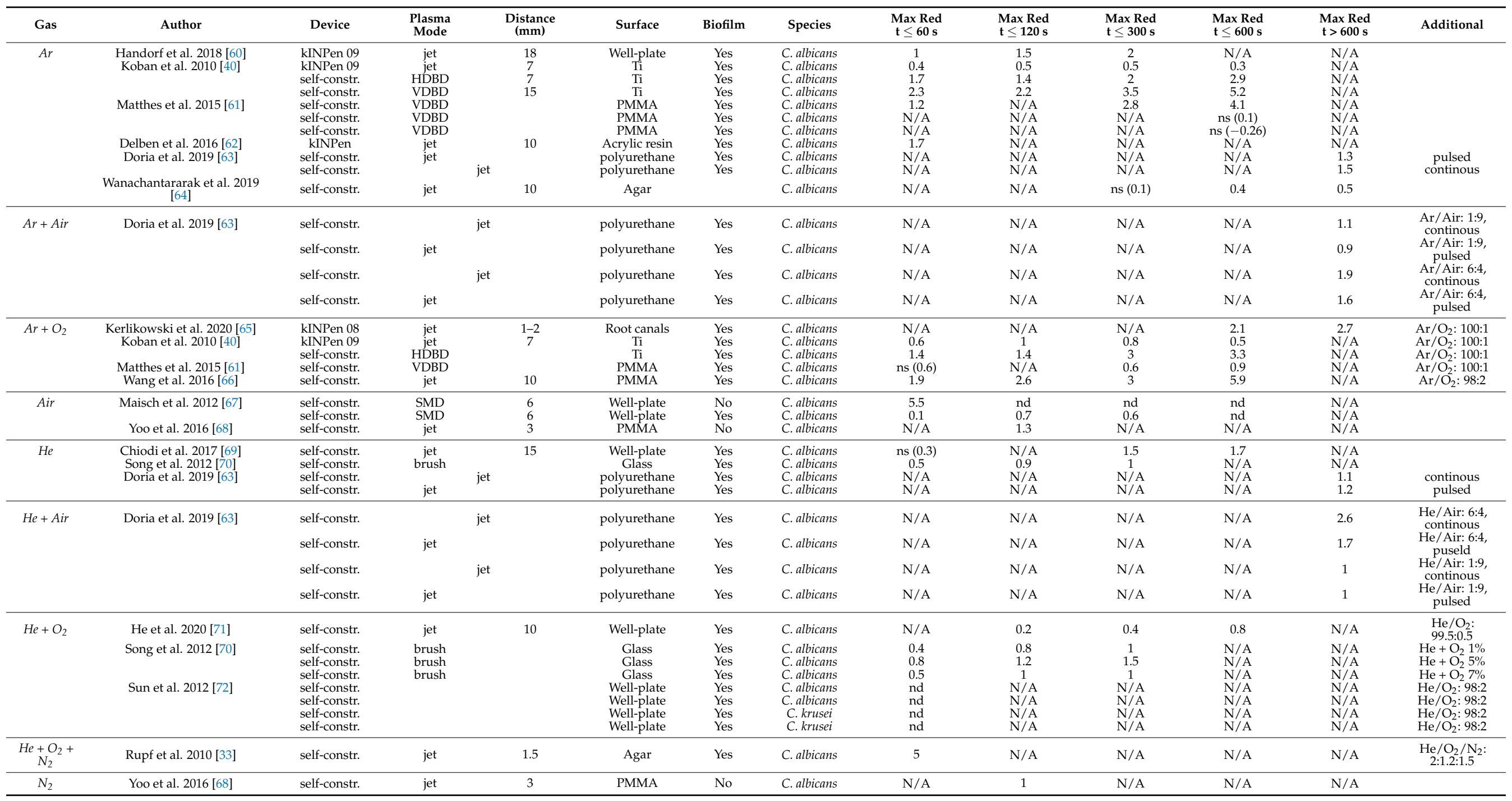




\subsection{Oral Streptococci}

In total, 15 studies exposed streptococci biofilms to plasma, utilizing either different noble gases or ambient air to apply the plasma to the microbes (Table 2). More than half of the studies used an argon plasma device. In the shortest treatment interval of up to $60 \mathrm{~s}$, some groups demonstrated bacterial elimination below the detection level [21,28], whereas others found no significant reduction $[19,20,22,25]$. For the other time intervals, the RF ranged from no reduction [22] to $3.8 \log _{10} \mathrm{CFU}$ [26] within $120 \mathrm{~s}$ and from no reduction [22,25] to complete elimination of CFU [24] in $300 \mathrm{~s}$, respectively. Koban et al. applied argon plasma for up to $600 \mathrm{~s}$ resulting in a decrease from $1.7 \log _{10} \mathrm{CFU}$ for a hollow DBD device to $5.8 \log _{10}$ CFU reduction for a volume DBD [25]. Blumhagen et al. found complete sterilization in $60 \mathrm{~s}$ [21]. Molnar et al. used a helium plasma device for 60 and $120 \mathrm{~s}$, respectively. $60 \mathrm{~s}$ resulted in a range of $1.3-2.3 \log _{10}$ CFU reduction, $120 \mathrm{~s}$ of treatment led to reduction below detection level [32]. For nitrogen plasma, studies with up to 60 and $120 \mathrm{~s}$ respectively were performed. In $60 \mathrm{~s}$, values ranged between 0.6 [34] and 1.5 [19], $120 \mathrm{~s}$ resulted in $1 \log _{10} \mathrm{CFU}$ reduction [34]. Two groups of authors tested DBD plasma devices, utilizing ambient air. RF values for $60 \mathrm{~s}$ ranged from $0.6-1.2 \log _{10}$ [31], and for up to $600 \mathrm{~s}$ from 2.4-2.6 $\log _{10} \mathrm{CFU}$ [30]. Rupf et al., who used a combination of helium, nitrous oxide, and oxygen, achieved higher RF values, ranging from 4.0 to $5.8 \log _{10} \mathrm{CFU}$ reduction in comparable treatment times [33].

\subsection{Lactobacilli}

In five studies, lactobacilli were treated with different plasma devices (Table 2). Most authors focused on short treatment times of $60 \mathrm{~s}$ with devices that used argon as a working gas. In this category, one group of authors found no reduction [19], two others a decrease of CFU below detection level [21,33]. The other two studies demonstrated a consistent but relatively low reduction rate of about $1.0-1.5 \log _{10}$ units. Rupf et al. showed reduction values of $4.5 \log _{10}$ and more using a mixture of helium, nitrous oxide and oxygen [33]. Treating for up to $60 \mathrm{~s}$ with nitrous oxide resulted in $0.6-1 \log _{10}$ CFU reduction, pure oxygen rendered values from $1.3 \log _{10}$ to complete sterilization and a combination of both gases showed no reduction up to $0.9 \log _{10} \mathrm{CFU}$ [19].

\subsection{Enterococcus faecalis}

In total, 22 studies exposed E. faecalis to plasma (Table 3). For the plain model experiments, the carrier gas was either argon or helium, in three studies an admixture of oxygen added to helium was used. Except for the $\mathrm{He} / \mathrm{O}_{2}$ plasma, the studies demonstrated a higher RF when the treatment time was longer. The reduction values for devices utilizing ambient air in all time intervals were demonstrated by two of the studies. The application of $60 \mathrm{~s}$ led to results ranging from no reduction to $7.9 \log _{10}$ reduction units [55]. For pure helium plasma, outcomes ranged from no reduction [45] to no detection of CFU within $60 \mathrm{~s}$ [42]. When admixing $\mathrm{O}_{2}$, values ranged from $2.9 \log _{10}$ for $10 \% \mathrm{O}_{2}$, and elimination of all CFU for $2.5 \% \mathrm{O}_{2}$ in up to $60 \mathrm{~s}$ treatment [43].

Six groups of authors utilized argon or $\mathrm{Ar} / \mathrm{O}_{2}$ plasma, eight helium or $\mathrm{He} / \mathrm{O}_{2}$ plasma on E. faecalis cultures inoculated in root canals of extracted teeth. In one study an air-driven jet was used additionally [52]. Ballout et al. used a DBD device and showed no significant reduction after an application time of $60 \mathrm{~s}$ [35]. Concerning plasma devices operating with pure argon, the reduction ranged from no reduction [35] to $3.2 \log _{10}$ units [37] for treatment up to $60 \mathrm{~s}$. A treatment time over 10 minutes led to a reduction of $1.8 \log _{10} \mathrm{CFU}$ in minimum [36] and to a non-detectable number in maximum [39]. For devices operating with argon plus an admixture of oxygen, values ranged from no reduction to $6.6 \log _{10}$ CFU for up to $120 \mathrm{~s}[38,40]$ Eight studies utilizing helium or helium plus admixtures were included. For pure helium, no reduction in the time less or equal $60 \mathrm{~s}$ was shown [45]. In the same study, the reduction in the group up to $300 \mathrm{~s}$ was $4.0 \log _{10}$ [45], whereas another group observed no reduction [44]. Higher RFs were achieved when admixing $\mathrm{O}_{2}$ to helium. For the interval up to $300 \mathrm{~s}$ the reduction ranged from 2.8 [47] to $5.1 \log _{10} \mathrm{CFU}$ [44]. A Chinese 
group investigated different admixtures to helium and $\mathrm{He} / \mathrm{O}_{2}$ gas. They let the working gas flow through hydrogen peroxide $\left(\mathrm{H}_{2} \mathrm{O}_{2}\right)$ [52] and sodium hypochloride $(\mathrm{NaOCl})$ [51] before the plasma was ignited. The values of the RF were: $4.9 \log _{10}\left(\mathrm{He}\right.$ plus $\left.\mathrm{H}_{2} \mathrm{O}_{2}\right)$ in up to $60 \mathrm{~s}, 7.0 \log _{10}\left(\mathrm{He}\right.$ plus $\left.\mathrm{H}_{2} \mathrm{O}_{2}\right)$ and $2.2 \log _{10}\left(\mathrm{He} / \mathrm{O}_{2}\right.$ plus $\left.\mathrm{NaOCl}\right)$ in up to $300 \mathrm{~s}, 2.4 \log _{10}$ $\left(\mathrm{He} / \mathrm{O}_{2}\right.$ plus $\left.\mathrm{NaOCl}\right)$ in up to $600 \mathrm{~s}$ and $5.4 \log _{10} \mathrm{CFU}$ for a treatment time over $600 \mathrm{~s}$.

\subsection{Periopathogens}

Three studies report on the activity of plasma on P. gingivalis (Table 4). For P. gingivalis, the maximum reduction in the time interval up to $60 \mathrm{~s}$ was $1.2 \log _{10} \mathrm{CFU}$ for argon [57]. Up to $120 \mathrm{~s}$ air plasma reached $4.0 \log _{10} \mathrm{CFU}$ [58]. In the group up to $300 \mathrm{~s}$ a RF of $1.2 \log _{10}$ CFU was achieved for argon [57] and helium plasma [59]. In the same interval, the air driven device obtained a reduction of $4.5 \log _{10} \mathrm{CFU}$ [58].

Three studies investigated the effect of CAP on A. actinomycetemcomitans (Table 4). Direct application of argon plasma showed a non-significant reduction compared to the control group at a treatment time of less than 1 minute [19], but the numbers of CFU decreased to a non-detectable level after more than 10 minutes [56]. When using different working gases, the values of RF increased. For oxygen plasma, a reduction of $1.9 \log _{10} \mathrm{CFU}$ and a reduction below the detection level was shown for up to $60 \mathrm{~s}$ at treatment distances of 20 and $2 \mathrm{~mm}$, respectively [19]. Using a DBD values for less than $1 \mathrm{~min}$ treatment time range from 1.1 to $2.2 \log _{10}$ and for 2 min from 1.8 to $2.8 \log _{10}$ CFU reduction [31]. Consistently, a time-dependent increase of the bacterial inactivation was evident among the studies.

\subsection{Candida}

Fourteen studies investigated the antifungal properties of CAP on C. albicans and Candida krusei (Table 5). Using pure Ar plasma, the RF ranged from no reduction for a jet device to $2.3 \log _{10} \mathrm{CFU}$ for volume DBD within a treatment time up to $60 \mathrm{~s}$, and from 0.5 for jet and $2.2 \log _{10}$ up to $120 \mathrm{~s}$ [73]. For the time interval up to $300 \mathrm{~s}$, the reductions were between no deactivation [64] and $3.5 \log _{10} \mathrm{CFU}$ [73]. Highly matured biofilm, grown for 7 and 16 days, showed no reduction after a treatment time of up to $600 \mathrm{~s}$ [61], whereas the values for 24-48 hours biofilm ranged from no reduction to $5.2 \log _{10}$ CFU dependent on the device type [73]. Admixing $\mathrm{O}_{2}$ to Ar the attained reduction was very similar compared to pure Ar. Kerlikowski et al. used an $\mathrm{Ar} / \mathrm{O}_{2}$ jet device to treat $\mathrm{C}$. albicans in root canals. The reduction achieved was $2.1 \mathrm{CFU}$ in less than $600 \mathrm{~s}$ [65]. $\mathrm{He} / \mathrm{O}_{2}$ resulted in total inactivation of a C. albicans and a C. krusei biofilm within $60 \mathrm{~s}$ [72], whereas another group of authors showed a reduction of 0.4 to $0.8 \log _{10}$ CFU dependent on the amount of oxygen admixed [70]. Using an air-based device, Maisch et al. attained a reduction of $5.5 \log _{10}$ in $60 \mathrm{~s}$ and a total elimination in all longer application intervals when treating planktonic C. albicans. For a 24 -hours biofilm, the RF was $0.7 \log _{10}$ after $120 \mathrm{~s}$ of treatment.

\subsection{Multi-Species Biofilm}

Two studies were performed investigating the effect on an ex-vivo, multi-species biofilm. The first one was published by Koban et al. analyzing the inactivation ability of different devices and oxygen admixtures on an aerobically cultured saliva biofilm. The reduction values for a pure argon jet were 1.6, 1.8, 1.5, and $1.4 \log _{10}$ for treatment intervals of up to $60,120,300$, and $600 \mathrm{~s}$, respectively. When adding oxygen, no reduction was found at any time interval. For a hollow DBD device values were 1.2, 1.6, 1.4 , and $1.5 \log _{10}$. An oxygen admixture resulted in no reduction for $60 \mathrm{~s}$, and 1.4, 3.1, $2.2 \log _{10}$ for 120, 300, and $600 \mathrm{~s}$. The highest reduction was obtained using a volume DBD device showing 3.9, 3.7, 5.3 , and $5.6 \log _{10}$ reduction in up to $60,120,300$, and $600 \mathrm{~s}$ treatment, respectively [25]. Secondly, one study was conducted treating an ex-vivo biofilm in a root canal. The obtained reduction was $1.0 \log _{10}$ CFU for an application time of $30 \mathrm{~min}$ in total [48]. 


\subsection{Quality Assessment}

The scores in the quality assessment ranged from $38 \%$ to $92 \%$ while $54 \%(11 / 55$ publications), $62 \%$ (10/55 publications), and $77 \%$ (10/55 publications) were achieved most frequently (Table S2). Eight articles were rated under $50 \%$. The inter-rater agreement was almost perfect $(\kappa=0.825)$. A point in item 5 was assigned when measures are described to protect specimens in surrounding wells, when not actively treated, to avoid cumulative effects caused by generated ozone and dehydration, for example. In two out of 55, a point for item 5 was obtained $[60,69]$.

\section{Discussion}

This systematic review intended to give an overview of the current in-vitro data concerning the antimicrobial effect of CAP on pathogens associated with dental diseases. Furthermore, factors which should be considered for further in-vitro studies and for future clinical applications were defined. Due to the high heterogeneity of the study designse.g., device parameters like power, frequency, working gas composition, application time, nozzle-specimen distance, underlying surface, and biofilm growth duration, that influence the outcome-a quantitative synthesis was not considered to be beneficial. In the majority of the studies, a reduction of 3 or more $\log _{10}$ units in vitro, which is considered to be bactericidal [74], was achieved within a treatment time of 2 minutes. The antibacterial activity increased in a time-dependent manner. This suggests that the application of CAP may represent a promising alternative or an adjunctive in antibacterial therapy.

Thirteen studies were conducted using a commercially available device. In 12 studies kINPen (neoplas med, Greifswald, Germany) was used, and in two of these 12 studies additionally PlasmaDerm (CYNOGY System, Duderstadt, Germany). One study tested Plasma R (Sweden \& Martina, Due Carrare, Italy). Forty-two groups of authors tested self-constructed devices. Various device parameters influenced the outcome and should therefore be taken into account in terms of reproducibility. An increase in power [28,42] enhanced the bacterial inactivation, but also results in an increase of plasma temperature [42]. Additionally, the gas flow influences the plasma temperature [75]. To avoid thermal damage of the treated tissues the device parameters need to be adjusted [76]. Some devices used in the included studies are not designed for a chairside usage, e.g., plasma was generated in a locked box filled with noble gas [56,67]. These studies rather proved the principle. For an implementation in clinical practice, the devices need to be designed as a hand-held device and a plasma generation with ambient air is favorable over pressurized gas cylinders.

The question, whether adding oxygen to a noble gas plasma device results in better $\mathrm{RF}$ values, remains unclear based on the included studies. This may be due to the fact that different types of devices were used and the advantageous effect of $\mathrm{O}_{2}$ admixture depends on the mode of plasma generation [25]. When adding oxygen near the grounded electrode of a DBD device, the reduction of CFU did not differ compared to pure argon [21]. For a DBD brush device, Chen et al. showed that adding 1.0 to $2.5 \%$ of oxygen to helium plasma was favorable in reducing E. faecalis biofilms. The admixture of $5 \%$ oxygen to helium also showed an increased antifungal effect on a C. albicans biofilm [70]. The antimicrobial properties of CAP are attributed to the generation of ROS, RNS, electrons, and UV radiation, whereas ROS is supposed to play the main part [3,77]. In the electric field between the two electrodes of the plasma device, the atoms of the noble gases are ionized, and electrons are released. These electrons react with oxygen and nitrogen and form radicals. In terms of a brush device, adding oxygen up to $2.5-5 \%$ of volume prior to the working gas ionization results in an increased microbicidal inactivation due to an elevated ROS generation. However, using higher percentages of oxygen had a contrary effect $[43,70]$. Song et al. explained that by a higher density of reactive species which results in augmented collisions with free electrons within the electric field and a lesser number of radicals in the effluent [70]. 
Admixture of hydrogen peroxide 3\% to helium also enhances the bacterial deactivation by enhancing ROS production as analyzed in the optical emission spectrum [52].

The values of RF varied markedly among the studies although a cluster within the ranges could be seen. Various devices were used which affect the outcome as described earlier. However, differences in specimen preparation, biofilm growth duration and bacterial characteristics also affected the results. To evaluate the possible indication of CAP application in the various fields of dentistry bacteria were grown on different surfaces like dentine or hydroxyapatite for cariogenic, titanium for peri-implant biofilms, or porcine bone for osteitis. Some studies simply used laboratory consumables like well-plates, agar in Petri dishes, cover glasses, or filter paper. Taken together the findings of the plain surface experiments, a bigger roughness of porous surfaces offers a cover to evade the plasma assault $[20,26,33]$. The achieved reduction in $\log _{10}$ CFU was also dependent on the inoculum size. Lower concentrations of $S$. mutans and L. acidophilus resulted in an increased inactivation $[21,28,32]$. In general, biofilm maturation was associated with an augmented resistance to CAP application in Gram-positive [22,24,31,55] and Gram-negative species [31]. The maturation of the biofilm is accompanied with the production of an extracellular matrix and an increase of biofilm thickness. Therefore, the deeper cell layers are better protected and need an extended treatment time for inactivation [24]. Fifteen studies were performed using a single-species S. mutans biofilm. This Gram-positive coccus is the most relevant pathogen in the establishment of carious lesions and therefore commonly used to investigate dental biofilms, but it is also recently advancing to a model organism for biofilm in microbiology due to its facilitated handling [78]. In terms of a caries preventive therapy, Sprague-Dawley rats were treated with CAP for $2 \mathrm{~min}$ on the molars of one side, the other side served as control. After six months the caries rate on the test side was decreased by $20 \%$ compared to the control [29]. Another possible clinical application could be the disinfection of the cavity after caries excavation. CAP eliminates remaining pathogens and alters the tooth surface. CAP treatment showed an increase in bonding strength in the dentin-adhesive interface [79-81] and enhanced enamel remineralization [82,83]. This may prevent secondary caries.

In an inhospitable environment like the oral cavity, microorganisms were forced to develop surviving strategies. Therefore, they organize themselves in a symbiotic community supporting each other [5]. Multi-species biofilms are less susceptible to chemical antimicrobial agents, antibiotics [84], and to CAP [85]. In the study of Koban et al., the RF for S. mutans biofilm was 3.1, whereas the RF for an ex-vivo, saliva biofilm was $1.6 \log _{10}$ CFU using an argon plasma jet for $60 \mathrm{~s}$ [25]. Another aspect of the latter publication should be taken into account when interpreting the results. The $S$. mutans and the saliva biofilms were incubated aerobically. The authors stated that this may result in a selection of more aerotolerant species within the saliva biofilm and a suppression of Gram-negative anaerobic species, which are more susceptible to ROS [25]. Therefore, the lower antibacterial effect can be caused by the multi-species biofilm or by the pre-treatment selection due to the aerobic incubation. Furthermore, the altered biofilm composition may not represent the clinical reality.

Six studies elucidated the antibacterial effect on Gram-negative periopathogens P. gingivalis and A. actinomycetemcomitans. The effect of CAP on other microorganisms associated with periodontal disease [8] was not analyzed. Within the limitations of this review both periopathogens tend to be more susceptible to plasma treatment than the Gram-positive species. A higher susceptibility of Gram-negative organisms compared to Gram-positives is consistent with recent reports on non-oral species [86,87]. Yang et al. used ambient air as working gas. They showed a higher RF when compared with pure argon- [57] or pure helium-driven devices [59]. P. gingivalis was the only obligate anaerobic pathogen in the studies included and therefore maybe more sensitive to an elevated amount of ROS induced by plasma, although $P$. gingivalis developed various strategies to resist oxidative stress [88]. Bacterial decontamination is crucial in periodontal and peri-implant therapy. The macro- and micro-retentive surface of dental implants is challenging to decontaminate. 
Duske et al. treated subgingival biofilm on sand-blasted and etched titanium discs. The SEM images showed that only a combined treatment with a titanium brush and CAP resulted in an adequate decontamination [89]. In the combination of air abrasion and CAP, CAP did not result in additional effect. In this study, air abrasion by itself resulted in complete biofilm elimination. These tests were performed with an optimal access to the treated surface [90]. The activity of different decontamination methods in correlation to the defect angulation was further investigated in vitro. The authors showed for all instruments a decrease in decontamination depending on the steepness of the defect and no instrument achieved complete decontamination in steep defects [91]. Therefore, in a clinical setting, an adjunctive antiseptic together with a mechanical decontamination might be beneficial as shown in the literature [92]. CAP application may be a promising alternative to the current adjunctives. Additional application of CAP resulted in significant higher peri-implant bone level and less inflammation compared to conventional treatment with plastic curettes in a ligature-induced peri-implant disease model in beagle dogs 3 months after the treatment. Furthermore, levels of $P$. gingivalis and Tannerella forsythia were significantly decreased compared to the control [93]. In the only RCT published, patients were treated with adjunctive CAP and showed significant more attachment level gain in severe periodontal pockets and a reduced load of periopathogens compared to conventional treatment 3 months after therapy [94].

The antifungal effect of CAP on C. albicans was investigated in 14 studies, 13 on plain surfaces, and 1 in an endodontic model [65]. In accordance with the findings from the bacterial experiments, the reduction increased with in a time-dependent manner. Adding oxygen had an advantageous effect when using a DBD brush device [70], equivalent to the experiments done by Chen et al. [43], but also when using a jet device [73]. The reduction values in the included studies seemed to be lower than for bacterial species. This may be to a higher resistance of the aerobe yeasts to CAP-generated ROS [95]. Biofilm maturation resulted in significant lower reductions [61,67].

Üreyen et al. demonstrated a RF of $3.1 \log _{10}$, when sampling the bacteria with paper points after treatment with $\mathrm{He} / \mathrm{O}_{2}$ plasma for $5 \mathrm{~min}$. Additionally, they separated the roots in thirds, enlarged the canals with burs and recovered the bacteria from the gained dentin chips. The values for the coronal, middle and apical third were $3.2 \log _{10}$, below detection level and $3.4 \log _{10}$, respectively. This shows that the antibacterial effect can be substantiated over the total length of the root canal [50]. E. faecalis is capable of penetrating the radial dentin tubuli up to $1000 \mu \mathrm{m}$ [7] and may reinfect the filled root canal system after the primary treatment. It is a predominant pathogen in secondary endodontic infections due to its increased resistance against antiseptics [96]. Herbst et al. additionally analyzed the penetration depth effect of plasma. The RF was 3.4, 2.1, and $1.4 \log _{10}$ for the perpendicular dentin sections of $0-300 \mu \mathrm{m}, 300-500 \mu \mathrm{m}$, and 500-800 $\mu \mathrm{m}$, respectively [37]. For $\mathrm{NaOCl}$, penetration depths of approximately $100-300 \mu \mathrm{m}$ in maximum-when activated-are described in the literature [97-100]. Herbst et al. showed a higher RF for CHX 2\% compared to CAP in the 500-800 $\mu \mathrm{m}$ layer [37]. However, there were also contrary reports in regard to the standard irrigants used for endodontic treatment. CAP showed a similar [47] or even slightly better reduction on E. faecalis biofilms compared to CHX $2 \%[37,39]$, and a similar [38] or lower RF compared to $\mathrm{NaOCl}[35,48,50]$.

When treating a C. albicans biofilm, CAP showed a better antifungal effect compared to $\mathrm{CHX} 2 \%$ and $\mathrm{NaOCl}$ in a 6 and $12 \mathrm{~min}$ application time [65]. Against a multi-species, ex-vivo biofilm $\mathrm{NaOCl}$ was far more effective than CAP resulting in a reduction of $4.5 \log _{10}$ compared to $1.0 \log _{10}$, respectively. The authors argue that even when inserting the plasma needle up to $15 \mathrm{~mm}$ into the root canal the plasma effluent is unable to interact over a longer distance [48]. Contrary findings were made by Du et al. showing no significant difference in the reduction between straight and complex canal anatomies even when inserting plasma nozzle only into the canal orifice [47]. Another interesting aspect of plasma application is the reduction of the surface tension [101]. An additional advantageous effect on the irrigants' disinfecting capability $[65,102]$ and an improved adhesion of the restorative 
material, especially after $\mathrm{NaOCl}$ rinsing $[77,103]$, makes CAP a promising extension to the established endodontic treatment protocols. In terms of oral candidiasis, BALB/c mice were infected with $C$. albicans and treated with CAP 5 days consecutively. Four minutes of treatment appeared ideal for adequate reduction and no damage of the superficial epithelium [71].

An assessment tool was designed to evaluate the reproducibility of the study protocols. The quality of the studies ranged from 32-92\%. Less than half of the studies (23 of 55) had a quality score of $69 \%$ or higher. In nine studies the protocol was described so insufficiently that the quality score was under $50 \%$. When authors fail to give relevant parameters, the experiments can hardly be repeated and compared. A limitation of this article is that due to the heterogeneous results by reason of device parameters and experimental settings a metaanalysis could not be performed. To access appropriate publications referring to our study question we performed a database search and only included research articles. Generally, studies with a high effect of a new treatment option may be published in peer-reviewed journals more often than studies showing a small impact of a treatment. Some results of the studies included in our review were not significantly different to the control, therefore an overestimated effect of CAP due to a publication bias is rather improbable.

\section{Conclusions}

The available evidence from in-vitro studies suggests that CAP is a promising tool in combating dental biofilms. Significant reductions can be achieved in a feasible treatment time, although the current data showed a broad range of values. Underlying mechanisms and specific plasma microbe interactions are not fully understood yet and discussed controversially in the literature. Additional studies are needed to enlighten the correlation of power and oxygen admixture with regards to the type of device. Furthermore, brush devices igniting plasma in ambient air seem to be auspicious because no gas tanks are necessary and therefore the clinical implementation of CAP might be easier. To compare the activity of different devices, the experimental set-up needs to be standardized to reduce variations in outcome determining factors like specimen preparation, inoculum size, growth duration of the biofilm, and treatment times. Most studies analyze the antimicrobial effect on single-species biofilms. Multi-species biofilms are more challenging and clinically more relevant. More studies using predetermined biofilm compositions need to be done. Finally, animal and clinical studies are required to confirm the results found in these invitro experiments. Possible indications in cariology, endodontology, periodontology, and implantology are conceivable.

Supplementary Materials: The following are available online at https:/ / www.mdpi.com/2079-638 2/10/2/211/s1, Table S1: Data extraction; Table S2: Quality assessment.

Author Contributions: G.J. and D.M. defined the search strategy, carried out the database searching, screened the literature, extracted the data, and wrote manuscript draft. S.E. and A.S. supervised and coached G.J. and D.M. during the entire project. W.P., S.M., A.S. and S.E. reviewed the manuscript. All authors have read and agreed to the published version of the manuscript.

Funding: This research received no external funding.

Data Availability Statement: Data is contained within the article or supplementary material.

Conflicts of Interest: The authors declare no conflict of interest.

\section{References}

1. H.-R.; von Woedtke, T.; Weltmann, K.-D. (Eds.) Plasmamedizin: Kaltplasma in der Medizinischen Anwendung; Metelmann, Springer: Berlin/Heidelberg, Germany, 2016; ISBN 978-3-662-52644-6.

2. Gherardi, M.; Tonini, R.; Colombo, V. Plasma in Dentistry: Brief History and Current Status. Trends Biotechnol. 2018, 36, 583-585. [CrossRef]

3. Lackmann, J.-W.; Bandow, J.E. Inactivation of microbes and macromolecules by atmospheric-pressure plasma jets. Appl. Microbiol. Biotechnol. 2014, 98, 6205-6213. [CrossRef] 
4. Müller, L.K.; Jungbauer, G.; Jungbauer, R.; Wolf, M.; Deschner, J. Biofilm and Orthodontic Therapy. In Oral Biofilms; Eick, S., Ed.; S. Karger AG: Berlin, Germany, 2020; pp. 201-213. ISBN 978-3-318-06851-1.

5. Takahashi, N. Microbial ecosystem in the oral cavity: Metabolic diversity in an ecological niche and its relationship with oral diseases. Int. Congr. Ser. 2005, 1284, 103-112. [CrossRef]

6. Caufield, P.W.; Schön, C.N.; Saraithong, P.; Li, Y.; Argimón, S. Oral Lactobacilli and Dental Caries: A Model for Niche Adaptation in Humans. J. Dent. Res. 2015, 94, 110S-118S. [CrossRef]

7. Haapasalo, M.; Orstavik, D. In vitro infection and disinfection of dentinal tubules. J. Dent. Res. 1987, 66, 1375-1379. [CrossRef]

8. Socransky, S.S.; Haffajee, A.D.; Cugini, M.A.; Smith, C.; Kent, R.L. Microbial complexes in subgingival plaque. J. Clin. Periodontol. 1998, 25, 134-144. [CrossRef]

9. Hajishengallis, G.; Darveau, R.P.; Curtis, M.A. The keystone-pathogen hypothesis. Nat. Rev. Microbiol. 2012, 717-725. [CrossRef]

10. Moher, D.; Liberati, A.; Tetzlaff, J.; Altman, D.G. Preferred reporting items for systematic reviews and meta-analyses: The PRISMA statement. PLoS Med. 2009, 6, e1000097. [CrossRef] [PubMed]

11. US Environmental Protection Agency Office of Pesticide Programs. Protocol for the Evaluation of Bactericidal Activity of Hard, Non-Porous Copper/Copper-Alloy Surfaces; Environmental Science Center: Fort Meade, MD, USA, 2015.

12. European Committee for Standardization. Chemical Disinfectants and Antiseptics-Quantitative Carrier Test for the Evaluation of Bactericidal Activity for Instruments Used in the Medical Area-Test Method and Requirements (Phase 2, Step 2); EN 14561:2006; Beuth: Berlin, Germany, 2006.

13. European Committee for Standardization. Chemical Disinfectants and Antiseptics-Quantitative Carrier Test for the Evaluation of Fungicidal or Yeasticidal Activity for Instruments Used in the Medical Area-Test Method and Requirements (Phase 2, Step 2); EN 14562:2006; Beuth: Berlin, Germany, 2006.

14. International Organization for Standardization. Sterilization of Medical Devices-Microbiological Methods—Part 1: Determination of a Population of Microorganisms on Products; ISO 11737-1:2006; AAMI: Arlington, VA, USA, 2006.

15. Chyderiotis, S.; Legeay, C.; Verjat-Trannoy, D.; Le Gallou, F.; Astagneau, P.; Lepelletier, D. New insights on antimicrobial efficacy of copper surfaces in the healthcare environment: A systematic review. Clin. Microbiol. Infect. 2018, 1130-1138. [CrossRef]

16. Koo, T.K.; Li, M.Y. A Guideline of Selecting and Reporting Intraclass Correlation Coefficients for Reliability Research. J. Chiropr. Med. 2016, 15, 155-163. [CrossRef]

17. Cohen, J. A Coefficient of Agreement for Nominal Scales. Educ. Psychol. Meas. 1960, 20, 37-46. [CrossRef]

18. Landis, J.R.; Koch, G.G. The measurement of observer agreement for categorical data. Biometrics 1977, 33, 159-174. [CrossRef] [PubMed]

19. Abonti, T.R.; Kaku, M.; Kojima, S.; Sumi, H.; Yamamoto, T.; Yashima, Y.; Miyahara, H.; Okino, A.; Kawata, T.; Tanne, K.; et al. Irradiation effects of low temperature multi gas plasma jet on oral bacteria. Dent. Mater. J. 2016, 35, 822-828. [CrossRef] [PubMed]

20. Abu-Sirhan, S.; Hertel, M.; Preissner, S.; Wirtz, H.C.; Herbst, S.R.; Pierdzioch, P.; Raguse, J.D.; Hartwig, S. Bactericidal efficacy of cold plasma in processed bone. A new approach for adjuvant therapy of medication-related osteonecrosis of the jaw? Clin. Plasma Med. 2016, 4, 9-13. [CrossRef]

21. Blumhagen, A.; Singh, P.; Mustapha, A.; Chen, M.; Wang, Y.; Yu, Q. Plasma Deactivation of Oral Bacteria Seeded on Hydroxyapatite Disks as Tooth Enamel Analogue. Am. J. Dent. 2014, 27, 84-90.

22. Gorynia, S.; Koban, I.; Matthes, R.; Welk, A.; Gorynia, S.; Hübner, N.-O.; Kocher, T.; Kramer, A. In vitro efficacy of cold atmospheric pressure plasma on S. sanguinis biofilms in comparison of two test models. GMS Hyg. Infect. Control 2013, 8. [CrossRef]

23. Hertel, M.; Schwill-Engelhardt, J.; Gerling, T.; Weltmann, K.-D.; Imiolczyk, S.M.; Hartwig, S.; Preissner, S. Antibacterial efficacy of plasma jet, dielectric barrier discharge, chlorhexidine, and silver diamine fluoride varnishes in caries lesions. Plasma Med. 2018, 8, 73-82. [CrossRef]

24. Huang, W.-K.; Weng, C.-C.; Liao, J.-D.; Wang, Y.-C.; Chuang, S.-F. Capillary-tube-based micro-plasma system for disinfecting dental biofilm. Int. J. Radiat. Biol. 2013, 89, 364-370. [CrossRef] [PubMed]

25. Koban, I.; Holtfreter, B.; Hübner, N.-O.; Matthes, R.; Sietmann, R.; Kindel, E.; Weltmann, K.-D.; Welk, A.; Kramer, A.; Kocher, T. Antimicrobial efficacy of non-thermal plasma in comparison to chlorhexidine against dental biofilms on titanium discs in vitro-Proof of principle experiment. J. Clin. Periodontol. 2011, 38, 956-965. [CrossRef]

26. Park, S.R.; Lee, H.W.; Hong, J.W.; Lee, H.J.; Kim, J.Y.; Choi, B.; Kim, G.C.; Jeon, Y.C. Enhancement of the killing effect of low-temperature plasma on Streptococcus mutans by combined treatment with gold nanoparticles. J. Nanobiotechnol. $2014,12,29$. [CrossRef]

27. Preissner, S.; Wirtz, H.C.; Tietz, A.-K.; Abu-Sirhan, S.; Herbst, S.R.; Hartwig, S.; Pierdzioch, P.; Schmidt-Westhausen, A.M.; Dommisch, H.; Hertel, M. Bactericidal efficacy of tissue tolerable plasma on microrough titanium dental implants: An in-vitrostudy. J. Biophotonics 2016, 9, 637-644. [CrossRef]

28. Yang, B.; Chen, J.; Yu, Q.; Li, H.; Lin, M.; Mustapha, A.; Hong, L.; Wang, Y. Oral Bacterial Deactivation Using a Low-Temperature Atmospheric Argon Plasma Brush. J. Dent. 2011, 39, 48-56. [CrossRef] [PubMed]

29. Hong, Q.; Dong, X.; Chen, M.; Sun, H.; Hong, L.; Wang, Y.; Li, H.; Yu, Q. An in vitro and in vivo study of plasma treatment effects on oral biofilms. J. Oral Microbiol. 2019, 11. [CrossRef] [PubMed]

30. Kovalová, Z.; Zahoran, M.; Zahoranová, A.; Machala, Z. Streptococci biofilm decontamination on teeth by low-temperature air plasma of dc corona discharges. J. Phys. D Appl. Phys. 2014, 47. [CrossRef] 
31. Liguori, A.; Cochis, A.; Stancampiano, A.; Laurita, R.; Azzimonti, B.; Sorrentino, R.; Varoni, E.M.; Petri, M.; Colombo, V.; Gherardi, M.; et al. Cold atmospheric plasma treatment affects early bacterial adhesion and decontamination of soft reline palatal obturators. Clin. Plasma Med. 2017, 7-8, 36-45. [CrossRef]

32. Molnar, I.; Papp, J.; Simon, A.; Anghel, S.D. Deactivation of Streptococcus mutans biofilms on a tooth surface using He dielectric barrier discharge at atmospheric pressure. Plasma Sci. Technol. 2013, 15, 535-541. [CrossRef]

33. Rupf, S.; Lehmann, A.; Hannig, M.; Schäfer, B.; Schubert, A.; Feldmann, U.; Schindler, A. Killing of adherent oral microbes by a non-thermal atmospheric plasma jet. J. Med. Microbiol. 2010, 59, 206-212. [CrossRef]

34. Yoo, E.-M.; Choi, Y.-R.; Kang, M.-K. Antimicrobial Efficacy of Nitrogen-Based Non-thermal Atmospheric Pressure Plasma Jet on Dental Biofilm. Iran. J. Sci. Technol. Trans. A Sci. 2020, 44, 1541-1547. [CrossRef]

35. Ballout, H.; Hertel, M.; Doehring, J.; Kostka, E.; Hartwig, S.; Paris, S.; Preissner, S. Effects of plasma jet, dielectric barrier discharge, photodynamic therapy and sodium hypochlorite on infected curved root canals. J. Biophotonics 2018, 11. [CrossRef]

36. Hüfner, A.; Steffen, H.; Holtfreter, B.; Schlüter, R.; Duske, K.; Matthes, R.; von Woedtke, T.; Weltmann, K.-D.; Kocher, T.; Jablonowski, L. Effects of Non-Thermal Atmospheric Pressure Plasma and Sodium Hypochlorite Solution on Enterococcus faecalis Biofilm: An Investigation in Extracted Teeth. Plasma Process. Polym. 2017, 14. [CrossRef]

37. Herbst, S.R.; Hertel, M.; Ballout, H.; Pierdzioch, P.; Weltmann, K.-D.; Wirtz, H.C.; Abu-Sirhan, S.; Kostka, E.; Paris, S.; Preissner, S. Bactericidal Efficacy of Cold Plasma at Different Depths of Infected Root Canals In Vitro. Open Dent. J. 2015, 9, 486-491. [CrossRef] [PubMed]

38. Habib, M.; Hottel, T.L.; Hong, L. Antimicrobial effects of non-thermal atmospheric plasma as a novel root canal disinfectant. Clin. Plasma Med. 2014, 2, 17-21. [CrossRef]

39. Li, Y.; Sun, K.; Ye, G.; Liang, Y.; Pan, H.; Wang, G.; Zhao, Y.; Pan, J.; Zhang, J.; Fang, J. Evaluation of Cold Plasma Treatment and Safety in Disinfecting 3-week Root Canal Enterococcus faecalis Biofilm in Vitro. J. Endod. 2015, 41, 1325-1330. [CrossRef]

40. Pan, J.; Sun, K.; Liang, Y.; Sun, P.; Yang, X.; Wang, J.; Zhang, J.; Zhu, W.; Fang, J.; Becker, K.H. Cold plasma therapy of a tooth root canal infected with enterococcus faecalis biofilms in vitro. J. Endod. 2013, 39, 105-110. [CrossRef] [PubMed]

41. Wang, R.; Zhou, H.; Sun, P.; Wu, H.; Pan, J.; Zhu, W.; Zhang, J.; Fang, J. The effect of an atmospheric pressure, DC nonthermal plasma microjet on tooth Root Canal, dentinal tubules infection and reinfection prevention. Plasma Med. 2011, 1, 143-155. [CrossRef]

42. Chen, W.; Huang, J.; Du, N.; Liu, X.-D.; Lv, G.-H.; Wang, X.-Q.; Zhang, G.-P.; Guo, L.-H.; Yang, S.-Z. Deactivation of enterococcus faecalis bacteria by an atmospheric cold plasma brush. Chin. Phys. Lett. 2012, 29. [CrossRef]

43. Chen, W.; Huang, J.; Du, N.; Liu, X.-D.; Wang, X.-Q.; Lv, G.-H.; Zhang, G.-P.; Guo, L.-H.; Yang, S.-Z. Treatment of enterococcus faecalis bacteria by a helium atmospheric cold plasma brush with oxygen addition. J. Appl. Phys. 2012, 112. [CrossRef]

44. Armand, A.; Khani, M.; Asnaashari, M.; AliAhmadi, A.; Shokri, B. Comparison study of root canal disinfection by cold plasma jet and photodynamic therapy. Photodiagn. Photodyn. 2019, 26, 327-333. [CrossRef]

45. Simoncelli, E.; Barbieri, D.; Laurita, R.; Liguori, A.; Stancampiano, A.; Viola, L.; Tonini, R.; Gherardi, M.; Colombo, V. Preliminary investigation of the antibacterial efficacy of a handheld Plasma Gun source for endodontic procedures. Clin. Plasma Med. 2015, 3, 77-86. [CrossRef]

46. Jiang, C.; Schaudinn, C.; Jaramillo, D.E.; Webster, P.; Costerton, J.W. In Vitro Antimicrobial Effect of a Cold Plasma Jet against Enterococcus faecalis Biofilms. ISRN Dent. 2012, 2012. [CrossRef]

47. Du, T.; Ma, J.; Yang, P.; Xiong, Z.; Lu, X.; Cao, Y. Evaluation of antibacterial effects by atmospheric pressure nonequilibrium plasmas against enterococcus faecalis biofilms in vitro. J. Endod. 2012, 38, 545-549. [CrossRef] [PubMed]

48. Schaudinn, C.; Jaramillo, D.; Freire, M.O.; Sedghizadeh, P.P.; Nguyen, A.; Webster, P.; Costerton, J.W.; Jiang, C. Evaluation of a non-thermal plasma needle to eliminate ex vivo biofilms in root canals of extracted human teeth. Int. Endod. J. 2013, 46, 930-937. [CrossRef] [PubMed]

49. Lu, X.; Cao, Y.; Yang, P.; Xiong, Q.; Xiong, Z.; Xian, Y.; Pan, Y. An RC plasma device for sterilization of root canal of teeth. IEEE Trans. Plasma Sci. 2009, 37, 668-673. [CrossRef]

50. Üreyen Kaya, B.; Kececi, A.D.; Güldas, H.E.; Cetin, E.S.; Öztürk, T.; Öksuz, L.; Bozduman, F. Efficacy of endodontic applications of ozone and low-temperature atmospheric pressure plasma on root canals infected with Enterococcus faecalis. Lett. Appl. Microbiol. 2014, 58, 8-15. [CrossRef]

51. Zhou, X.; Xiong, Z.; Cao, Y.; Lu, X.; Liu, D. The antimicrobial activity of an atmospheric-pressure room-temperature plasma in a simulated root-canal model infected with enterococcus faecalis. IEEE Trans. Plasma Sci. 2010, 38, 3370-3374. [CrossRef]

52. Zhou, X.-C.; Li, Y.-L.; Liu, D.-X.; Cao, Y.-G.; Lu, X.-P. Bactericidal effect of plasma jet with helium flowing through $3 \%$ hydrogen peroxide against Enterococcus faecalis. Exp. Med. 2016, 12, 3073-3077. [CrossRef]

53. Cao, Y.; Yang, P.; Lu, X.; Xiong, Z.; Ye, T.; Xiong, Q.; Sun, Z. Efficacy of atmospheric pressure plasma as an antibacterial agent against enterococcus faecalis in vitro. Plasma Sci. Technol. 2011, 13. [CrossRef]

54. Chang, Y.-T.; Chen, G. Oral bacterial inactivation using a novel low-temperature atmospheric-pressure plasma device. J. Dent. Sci. 2016, 11, 65-71. [CrossRef] [PubMed]

55. Theinkom, F.; Singer, L.; Cieplik, F.; Cantzler, S.; Weilemann, H.; Cantzler, M.; Hiller, K.-A.; Maisch, T.; Zimmermann, J.L. Antibacterial efficacy of cold atmospheric plasma against Enterococcus faecalis planktonic cultures and biofilms in vitro. PLoS ONE 2019, 14, e0223925. [CrossRef] 
56. Annunziata, M.; Canullo, L.; Donnarumma, G.; Caputo, P.; Nastri, L.; Guida, L. Bacterial inactivation/sterilization by argon plasma treatment on contaminated titanium implant surfaces:In vitro study. Med. Oral Patol. Oral Cir. Bucal 2016, 21, e118-21. [CrossRef]

57. Carreiro, A.F.P.; Delben, J.A.; Guedes, S.; Silveira, E.J.D.; Janal, M.N.; Vergani, C.E.; Pushalkar, S.; Duarte, S. Low-temperature plasma on peri-implantÔÇôrelated biofilm and gingival tissue. J. Periodontol. 2019, 90, 507-515. [CrossRef] [PubMed]

58. Yang, Y.; Guo, J.; Zhou, X.; Liu, Z.; Wang, C.; Wang, K.; Zhang, J.; Wang, Z. A novel cold atmospheric pressure air plasma jet for peri-implantitis treatment: An in vitro study. Dent. Mater. J. 2018, 37, 157-166. [CrossRef]

59. Lee, J.-Y.; Kim, K.-H.; Park, S.-Y.; Yoon, S.-Y.; Kim, G.-H.; Lee, Y.-M.; Rhyu, I.-C.; Seol, Y.-J. The bactericidal effect of an atmosphericpressure plasma jet on Porphyromonas gingivalis biofilms on sandblasted and acid-etched titanium discs. J. Periodontal Implant Sci. 2019, 49, 319-329. [CrossRef] [PubMed]

60. Handorf, O.; Weihe, T.; Bekeschus, S.; Graf, A.C.; Schnabel, U.; Riedel, K.; Ehlbeck, J. Nonthermal Plasma Jet Treatment Negatively Affects the Viability and Structure of Candida albicans SC5314 Biofilms. Appl. Environ. Microbiol. 2018, 84. [CrossRef]

61. Matthes, R.; Jablonowski, L.; Koban, I.; Quade, A.; Hübner, N.-O.; Schlueter, R.; Weltmann, K.-D.; von Woedtke, T.; Kramer, A.; Kocher, T. In vitro treatment of Candida albicans biofilms on denture base material with volume dielectric barrier discharge plasma (VDBD) compared with common chemical antiseptics. Clin. Oral Investig. 2015, 19, 2319-2326. [CrossRef] [PubMed]

62. Delben, J.A.; Zago, C.E.; Tyhovych, N.; Duarte, S.; Vergani, C.E. Effect of Atmospheric-Pressure Cold Plasma on Pathogenic Oral Biofilms and In Vitro Reconstituted Oral Epithelium. PLoS ONE 2016, 11, e0155427. [CrossRef] [PubMed]

63. Doria, A.C.O.C.; Figueira, F.R.; de Lima, J.S.B.; Figueira, J.A.N.; Castro, A.H.R.; Sismanoglu, B.N.; Petraconi, G.; Maciel, H.S.; Khouri, S.; Pessoa, R.S. Inactivation of Candida albicans biofilms by atmospheric gliding arc plasma jet: Effect of gas chemistry/flow and plasma pulsing. Plasma Res. Express 2019, 1. [CrossRef]

64. Wanachantararak, P.; Suanpoot, P.; Nisoa, M. Inhibitory activity of cold atmospheric plasma on Candida albicans. Walailak J. Sci. Technol. 2019, 16, 401-408. [CrossRef]

65. Kerlikowski, A.; Matthes, R.; Pink, C.; Steffen, H.; Schlüter, R.; Holtfreter, B.; Weltmann, K.-D.; von Woedtke, T.; Kocher, T.; Jablonowski, L. Effects of cold atmospheric pressure plasma and disinfecting agents on Candida albicans in root canals of extracted human teeth. J. Biophotonics 2020. [CrossRef]

66. Wang, G.M.; Sun, P.P.; Pan, H.; Ye, G.P.; Sun, K.; Zhang, J.; Pan, J.; Fang, J. Inactivation of Candida albicans Biofilms on Polymethyl Methacrylate and Enhancement of the Drug Susceptibility by Cold $\mathrm{Ar} / \mathrm{O}_{2}$ Plasma Jet. Plasma Chem. Plasma Process. 2016, 36, 383-396. [CrossRef]

67. Maisch, T.; Shimizu, T.; Isbary, G.; Heinlin, J.; Karrer, S.; Klämpfl, T.G.; Li, Y.-F.; Morfill, G.; Zimmermann, J.L. Contact-Free Inactivation of Candida albicans Biofilms by Cold Atmospheric Air Plasma. Appl. Environ. Microbiol. 2012, 78, $4242-4247$. [CrossRef] [PubMed]

68. Yoo, E.-M.; Seo, H.-Y.; Choi, Y.-R.; Kang, M.-K. Inhibition of C. albicans formation by non-thermal atmospheric pressure plasma jet (NTAPPJ) on acrylic resin surface. Int. J. Bio-Sci. Bio-Technol. 2016, 8, 231-238. [CrossRef]

69. Chiodi Borges, A.; Castaldelli Nishime, T.M.; Kostov, K.G.; de Morais Gouvêa Lima, G.; Lacerda Gontijo, A.V.; de Carvalho, J.N.M.M.; Yzumi Honda, R.; Koga-Ito, C.Y. Cold atmospheric pressure plasma jet modulates Candida albicans virulence traits.. Clin. Plasma Med. 2017, 7-8, 9-15. [CrossRef]

70. Song, Y.; Liu, D.; Ji, L.; Wang, W.; Niu, J.; Zhang, X. Plasma inactivation of Candida albicans by an atmospheric cold plasma brush composed of hollow fibers. IEEE Trans. Plasma Sci. 2012, 40, 1098-1102. [CrossRef]

71. He, M.; Duan, J.; Xu, J.; Ma, M.; Chai, B.; He, G.; Gan, L.; Zhang, S.; Duan, X.; Lu, X.; et al. Candida albicans biofilm inactivated by cold plasma treatment in vitro and in vivo. Plasma Process. Polym. 2020, 17. [CrossRef]

72. Sun, Y.; Yu, S.; Sun, P.; Wu, H.; Zhu, W.; Liu, W.; Zhang, J.; Fang, J.; Li, R. Inactivation of Candida Biofilms by Non-Thermal Plasma and Its Enhancement for Fungistatic Effect of Antifungal Drugs. PLoS ONE 2012, 7, e40629. [CrossRef] [PubMed]

73. Koban, I.; Matthes, R.; Hübner, N.-O.; Welk, A.; Meisel, P.; Holtfreter, B.; Sietmann, R.; Kindel, E.; Weltmann, K.-D.; Kramer, A.; et al. Treatment of Candida albicans biofilms with low-temperature plasma induced by dielectric barrier discharge and atmospheric pressure plasma jet. New J. Phys. 2010, 12. [CrossRef]

74. Pankey, G.A.; Sabath, L.D. Clinical relevance of bacteriostatic versus bactericidal mechanisms of action in the treatment of Gram-positive bacterial infections. Clin. Infect. Dis. 2004, 864-870. [CrossRef]

75. Al-rawaf, A.F.; Fuliful, F.K.; Khalaf, M.K.; Oudah, H.K. Studying the non-thermal plasma jet characteristics and application on bacterial decontamination. J. Appl. Phys. 2018, 12, 45-51. [CrossRef]

76. Deng, X.; Shi, J.; Kong, M.G. Physical Mechanisms of Inactivation of Bacillus subtilis Spores Using Cold Atmospheric Plasmas. IEEE Trans. Plasma Sci. 2006, 34, 1310-1316. [CrossRef]

77. Bisag, A.; Manzini, M.; Simoncelli, E.; Stancampiano, A.; Tonini, R.; Gherardi, M.; Colombo, V. Cold atmospheric pressure plasma treatment to assist the restoration of the apical region of a root canal in endodontic procedures. Clin. Plasma Med. 2020, 19-20, 100100. [CrossRef]

78. Lemos, J.A.; Quivey, R.G.; Koo, H.; Abranches, J. Streptococcus mutans: A new Gram-positive paradigm? Microbiology 2013, 159, 436-445. [CrossRef]

79. Colombo, V.; Forgione, D.; Gherardi, M.; Laurita, R.; Simoncelli, E.; Nassar, M.; Stancampiano, A.; Tonini, R. Cold atmospheric pressure plasma treatment to improve the bonding strength of dentin-adhesive system interface in dental composite restoration. J. Appl. Biomater. Funct. Mater. 2017, 15, e280. [CrossRef] 
80. Dong, X.; Chen, M.; Wang, Y.; Yu, Q. A Mechanistic study of Plasma Treatment Effects on Demineralized Dentin Surfaces for Improved Adhesive/Dentin Interface Bonding. Clin. Plasma Med. 2014, 2, 11-16. [CrossRef] [PubMed]

81. Zhu, X.-M.; Zhou, J.-F.; Guo, H.; Zhang, X.-F.; Liu, X.-Q.; Li, H.-P.; Tan, J.-G. Effects of a modified cold atmospheric plasma jet treatment on resin-dentin bonding. Dent. Mater. J. 2018, 37, 798-804. [CrossRef]

82. Kim, Y.M.; Lee, H.Y.; Lee, H.J.; Kim, J.B.; Kim, S.; Joo, J.Y.; Kim, G.C. Retention Improvement in Fluoride Application with Cold Atmospheric Plasma. J. Dent. Res. 2018, 97, 179-183. [CrossRef] [PubMed]

83. El-Wassefy, N.A. Remineralizing effect of cold plasma and/or bioglass on demineralized enamel. Dent. Mater. J. 2017, 36, 157-167. [CrossRef] [PubMed]

84. Gilbert, P.; Das, J.; Foley, I. Biofilm susceptibility to antimicrobials. Adv. Dent. Res. 1997, 11, 160-167. [CrossRef]

85. Rao, Y.; Shang, W.; Yang, Y.; Zhou, R.; Rao, X. Fighting Mixed-Species Microbial Biofilms With Cold Atmospheric Plasma. Front. Microbiol. 2020, 11, 1000. [CrossRef] [PubMed]

86. Ermolaeva, S.A.; Varfolomeev, A.F.; Chernukha, M.Y.; Yurov, D.S.; Vasiliev, M.M.; Kaminskaya, A.A.; Moisenovich, M.M.; Romanova, J.M.; Murashev, A.N.; Selezneva, I.I.; et al. Bactericidal effects of non-thermal argon plasma in vitro, in biofilms and in the animal model of infected wounds. J. Med. Microbiol. 2011, 60, 75-83. [CrossRef]

87. Mai-Prochnow, A.; Clauson, M.; Hong, J.; Murphy, A.B. Gram positive and Gram negative bacteria differ in their sensitivity to cold plasma. Sci. Rep. 2016, 6, 38610. [CrossRef]

88. Henry, L.G.; McKenzie, R.M.E.; Robles, A.; Fletcher, H.M. Oxidative stress resistance in Porphyromonas gingivalis. Future Microbiol. 2012, 7, 497-512. [CrossRef] [PubMed]

89. Duske, K.; Jablonowski, L.; Koban, I.; Matthes, R.; Holtfreter, B.; Sckell, A.; Barbara Nebe, J.; von Woedtke, T.; Weltmann, K.D.; Kocher, T. Cold atmospheric plasma in combination with mechanical treatment improves osteoblast growth on biofilm covered titanium discs. Biomaterials 2015, 52, 327-334. [CrossRef] [PubMed]

90. Matthes, R.; Duske, K.; Kebede, T.G.; Pink, C.; Schlüter, R.; von Woedtke, T.; Weltmann, K.-D.; Kocher, T.; Jablonowski, L. Osteoblast growth, after cleaning of biofilm-covered titanium discs with air-polishing and cold plasma. J. Clin. Periodontol. 2017, 44, 672-680. [CrossRef] [PubMed]

91. Keim, D.; Nickles, K.; Dannewitz, B.; Ratka, C.; Eickholz, P.; Petsos, H. In vitro efficacy of three different implant surface decontamination methods in three different defect configurations. Clin. Oral Implant. Res. 2019. [CrossRef]

92. Schwarz, F.; Schmucker, A.; Becker, J. Efficacy of alternative or adjunctive measures to conventional treatment of peri-implant mucositis and peri-implantitis: A systematic review and meta-analysis. Int. J. Implant Dent. 2015, 1, 22. [CrossRef] [PubMed]

93. Shi, Q.; Song, K.; Zhou, X.; Xiong, Z.; Du, T.; Lu, X.; Cao, Y. Effects of non-equilibrium plasma in the treatment of ligature-induced peri-implantitis. J. Clin. Periodontol. 2015, 42, 478-487. [CrossRef] [PubMed]

94. Küçük, D.; Savran, L.; Ercan, U.K.; Yarali, Z.B.; Karaman, O.; Kantarci, A.; Sağlam, M.; Köseoğlu, S. Evaluation of efficacy of non-thermal atmospheric pressure plasma in treatment of periodontitis: A randomized controlled clinical trial. Clin. Oral Investig. 2020, 24, 3133-3145. [CrossRef] [PubMed]

95. Klämpfl, T.G.; Isbary, G.; Shimizu, T.; Li, Y.-F.; Zimmermann, J.L.; Stolz, W.; Schlegel, J.; Morfill, G.E.; Schmidt, H.-U. Cold atmospheric air plasma sterilization against spores and other microorganisms of clinical interest. Appl. Environ. Microbiol. 2012, 78, 5077-5082. [CrossRef] [PubMed]

96. Alghamdi, F.; Shakir, M. The Influence of Enterococcus faecalis as a Dental Root Canal Pathogen on Endodontic Treatment: A Systematic Review. Cureus 2020, 12. [CrossRef] [PubMed]

97. Faria, G.; Viola, K.S.; Coaguila-Llerena, H.; Oliveira, L.R.A.; Leonardo, R.T.; Aranda-García, A.J.; Guerreiro-Tanomaru, J.M. Penetration of sodium hypochlorite into root canal dentine: Effect of surfactants, gel form and passive ultrasonic irrigation. Int. Endod. J. 2019, 52, 385-392. [CrossRef]

98. Ghorbanzadeh, A.; Aminsobhani, M.; Sohrabi, K.; Chiniforush, N.; Ghafari, S.; Shamshiri, A.R.; Noroozi, N. Penetration Depth of Sodium Hypochlorite in Dentinal Tubules after Conventional Irrigation, Passive Ultrasonic Agitation and Nd:YAG Laser Activated Irrigation. J. Lasers Med. Sci. 2016, 7, 105-111. [CrossRef] [PubMed]

99. Wong, D.T.S.; Cheung, G.S.P. Extension of bactericidal effect of sodium hypochlorite into dentinal tubules. J. Endod. 2014, 40, 825-829. [CrossRef]

100. Zou, L.; Shen, Y.; Li, W.; Haapasalo, M. Penetration of sodium hypochlorite into dentin. J. Endod. 2010, 36, 793-796. [CrossRef] [PubMed]

101. Chen, M.; Zhang, Y.; Sky Driver, M.; Caruso, A.N.; Yu, Q.; Wang, Y. Surface modification of several dental substrates by non-thermal, atmospheric plasma brush. Dent. Mater. 2013, 29, 871-880. [CrossRef] [PubMed]

102. Koban, I.; Geisel, M.H.; Holtfreter, B.; Jablonowski, L.; Hübner, N.-O.; Matthes, R.; Masur, K.; Weltmann, K.-D.; Kramer, A.; Kocher, T. Synergistic Effects of Nonthermal Plasma and Disinfecting Agents against Dental Biofilms In Vitro. ISRN Dent. 2013, 2013. [CrossRef] [PubMed]

103. Abreu, J.L.B.D.; Prado, M.; Simão, R.A.; Silva, E.M.D.; Dias, K.R.H.C. Effect of Non-Thermal Argon Plasma on Bond Strength of a Self-Etch Adhesive System to NaOCl-Treated Dentin. Braz. Dent. J. 2016, 27, 446-451. [CrossRef] 